\title{
Is there an Effect of Serotonin on Attention Deficit Hyperactivity Disorder
}

\author{
Yunias Setiawati $^{1}$, H.J. Mukono ${ }^{2}$, Joni Wahyuhadi ${ }^{3}$, Endang Warsiki ${ }^{1}$, Sasanti Yuniar ${ }^{1}$ \\ ${ }^{1}$ Department of Psychiatric, Faculty of Medicine Universitas Airlangga, Dr. Soetomo General Hospital, \\ ${ }^{2}$ Department of Environmental Health, Faculty of Public Health Universitas Airlangga, ${ }^{3}$ Department of \\ Neurosurgery, Faculty of Medicine Universitas Airlangga, Dr. Soetomo General Hospital
}

\begin{abstract}
Background: Attention deficit hyperactivity disorder (ADHD) is a neurobiological disorder with a prevalence of 5\%-10\% in the world that negatively impacts school behavior and achievement. There have been many studies reveals that attention disorders are caused by the decreased levels of dopamine and norepinephrine neurotransmitter. However, particular concern nowadays are the emotional and behavioral problems. The emotional and behavioral problem is suspected to be caused by the decrease in serotonin level. The aim of this study was to determine the difference in serotonin level between ADHD and non-ADHD children.
\end{abstract}

Method: This study was an observational case-control study design using random sampling method. Subject of this study was children in Bina Karya Elementary School Surabaya. ADHD severity was assessed using Conners Abreviated Rating Scale. Examination of serotonin levels in blood was done by ELISA method. Informed consent was signed by parents before the study. Data was analyzed using independent T-test.

Results: 44 (23 ADHD and 21 non-ADHD) children from grade 1 to 6 was included in the study. Based on the gender, 13 children were girls and 31 children were boys. Serotonin level in ADHD children was significantly higher than non-ADHD children $(2.148 \pm 0.94$ vs $2.006 \pm 0.115 \mu \mathrm{mol} / \mathrm{L} ; \mathrm{p}=0.0001)$.

Conclusion: Serotonin level in ADHD children was significantly higher than non-ADHD children.

Keyword: Serotonin, ADHD, Abbreviated Conners Teacher Rating Scale.

\section{Introduction}

Attention deficit hyperactivity disorder (ADHD) is a neurobiological disorder with a prevalence of $5 \%-10 \%$ in the world that negatively impacts school behavior and achievement. The onset of this disorder usually appears in the school-age ${ }^{(1)}$. Many parents feel disconcerted in nurturingtheir children with ADHD since they often opposed, haphazardly behave, and disobey the rules ${ }^{(2,3)}$

\footnotetext{
Corresponding Author:

Yunias Setiawati

Department of Psychiatric, Faculty of Medicine Universitas Airlangga, Dr. Soetomo General Hospital e-mail: yunias.setiawati@gmail.com
}

Parents, especially mothers, often have to lose their jobs because they have to take care of their ADHD children $^{(4,5)}$. Teachers at school also often complain of being confused and discouraged in educating children with ADHD because they need extra attention while there are limited teachers available and a lot of students to be supervisedat one time ${ }^{(6-8)}$ ADHD often coexist with other disorders, such as anxiety, depression, and learning disorder due to short spans of attention, hyperactivity, and impulsive behavior ${ }^{(9-12)}$. Management of ADHD is multimodal, including pharmacotherapy and psychotherapy. Psychosocial therapy is also considered for parents that refuse pharmacotherapy ${ }^{(6,9,13-15)}$

There have been many studies reveals that attention disorders are caused by the decreased levels of dopamine and norepinephrine neurotransmitter ${ }^{(16)}$ However, 
particular concern nowadays are the emotional and behavioral problems. It is more severe than the communication difficulties in the family, as emotional and behavioral disorders will adversely affect the entire life span of an ADHD children ${ }^{(17)}$. The emotional and behavioral problem is suspected to be caused by the decrease in serotonin level. However, study about the effects of serotonin is very limited and the results are still controversial ${ }^{(18,19)}$.

Considering that the study about the effect of serotonin is very limited and the result is still controversial, authors conduct this study to determine the difference in serotonin level between ADHD and non-ADHD children.

\section{Method}

This study was an observational case-control study design using random sampling method. Subject of this study was children in Bina Karya Elementary School Surabaya. The inclusion criteria for the case group was ADHD children in class 1 to 6 , the mothers were not experiencing any psychosocial stressor during the study period, and both the mothers and the children were able to communicate using Indonesian language and being cooperative during the study. The inclusion criteria for the control group was non-ADHD children in class 1 to 6 , and both the mothers and the children were able to communicate using Indonesian language and being cooperative during the study. The exclusion criteria for the study was children with the others mental health condition.

ADHD scores was assessed using Abbreviated Conners Teacher Rating Scale in Indonesian version. Social Readjustment Rating Scale by Holmes and Rahe was used to assess psychosocial stressor of the mother (Holmes \& Rahe, 1967). Serotonin serum level was measured using ELISA method.

Shappiro-wilk test was used for the normality test. Independent T-test was used to analyze the difference between serotonin level in ADHD and non-ADHD children. SPSS 17.0.0 for windows software, 2007, SPSS Inc. Chicago, IL, USA and Microsoft Office 2013 was used for the statistical analysis test.

This study follows the principles of the Declaration of Helsinki. This study has received recommendation from Surabaya city government office before the study begins (Recommendation Number 070/1574/436.8.5/2018). Parents were given information for consent and signed the informed consent regarding the study prior to their involvement in the study. Details that might disclose the identity of the subjects under study were omitted.

\section{Results}

Table 1: Characteristic of the Subjects' Family

\begin{tabular}{|c|c|c|c|c|}
\hline & & Non ADHD N (\%) & ADHD N (\%) & Total \\
\hline \multirow{3}{*}{$\begin{array}{l}\text { Highest Education } \\
\text { Background }\end{array}$} & Junior high school & $11(50)$ & $11(50)$ & $22(100)$ \\
\hline & Senior high school & $7(41.2)$ & $10(58.8)$ & $17(100)$ \\
\hline & university & $3(47.7)$ & $2(52.3)$ & $5(100)$ \\
\hline \multirow{2}{*}{ Occupation } & Not work & $16(51.6)$ & $15(48.4)$ & $31(100)$ \\
\hline & Work & $5(38.5)$ & $8(51.5)$ & $13(100)$ \\
\hline \multirow{4}{*}{$\begin{array}{l}\text { Sufficiency of monthly } \\
\text { income }\end{array}$} & Not sufficient & $5(50)$ & $5(50)$ & $10(100)$ \\
\hline & Almostsufficient & $6(37.5)$ & $10(62.5)$ & $16(100)$ \\
\hline & Sufficient & $9(56.2)$ & $7(43.8)$ & $16(100)$ \\
\hline & Very sufficient & $1(47.7)$ & $1(52.3)$ & $2(100)$ \\
\hline \multirow{2}{*}{ Parents relationship } & Poor & 0 & $3(100)$ & $3(100)$ \\
\hline & Good & $21(51.2)$ & $20(48.8)$ & $41(100)$ \\
\hline \multirow{2}{*}{$\begin{array}{l}\text { Relationship among } \\
\text { family member }\end{array}$} & Poor & 0 & $5(100)$ & $5(100)$ \\
\hline & Good & $21(53.8)$ & $18(46.2)$ & $39(100)$ \\
\hline \multirow{2}{*}{$\begin{array}{l}\text { Family Member Social } \\
\text { interaction }\end{array}$} & Poor & $2(66.7)$ & $1(33.3)$ & $3(100)$ \\
\hline & Good & $19(46.3)$ & $22(53.7)$ & $41(100)$ \\
\hline
\end{tabular}


Characteristic of the subjects and the family: 21 non-ADHD children and 23 ADHD children was included in the study. Based on the gender, there were 13 girls (6 in non-ADHD group and 7 in ADHD group) and 31 boys (15 in non-ADHD group and 16 in ADHD group). From the mother highest education background, 22 parents had graduated from junior high school, 17 had graduated from senior high school education background, and 5 had graduated from university education background. Based on the occupation, 13 children had their mother worked, while 31 children had their mother not worked. From the sufficiency of the monthly income, only 18 family had sufficient monthly income. 3 family had a poor mother-father relationship, whilst 5 family had a poor family relationship (table 1).

Table 2. Serotonin Level in ADHD and Non-ADHD Children

\begin{tabular}{|l|c|c|}
\hline Variable & Mean & P \\
\cline { 1 - 2 } ADHD & $2.148 \pm 0.94 \mu \mathrm{mol} / \mathrm{L}$ & \multirow{2}{*}{0.0001} \\
\cline { 1 - 2 } Non-ADHD & $2.006 \pm 0.115 \mu \mathrm{mol} / \mathrm{L}$ & \\
\hline
\end{tabular}

Results Table 2. The mean serotonin level in ADHD children was $2.148 \pm 0.94 \mu \mathrm{mol} / \mathrm{L}$, while the mean serotonin level in non-ADHD children was $2.006 \pm 0.115$ $\mu \mathrm{mol} / \mathrm{L}$. Normality test showed that the data distribution was normal. Using independent T-test, it was found that serotonin level in ADHD was significantly higher than non-ADHD children $(\mathrm{p}=0.0001,95 \% \mathrm{CI}=0.780$ 0.206).

\section{Discussion}

From the demographic data of the subjects, there were 16 boys and 7 girls with ADHD. This result is consistent with the results of previous studies which found that the prevalence of ADHD was greater in boys ${ }^{(6,20,21)}$. Psychostimulant methylphenidate (MPH) and amphetamine (AMPH) are the first-line ADHD drug choice ${ }^{(22-25)}$ Both of these drugs primarily work on dopamine (D2) and noradrenaline (NA) system, but not on the serotonin system ${ }^{(8,26)}$. More than half of the subjects did not respond positively to the administration of this psychostimulant ${ }^{(6,27)}$ Not all parents agree with methylphenidate that affects appetite and inhibits growth when given to their children and also the risk of drug dependence or abuse on long-term use with adolescent subject ${ }^{(28)}$.

Serotonin selective reuptake inhibitors (SSRIs) that working in the serotonin system are the second- line treatment in ADHD management ${ }^{(13,29-33)}$. This fact becomes the basic etiologic hypothesis of serotonin to ADHD. Based on these results, hypotheses suggest that chronic serotonin deficiency causes hyperactivity and impulsivity symptoms in ADHD (19). The etiology of serotonin in ADHD up to now is not clearly known on brain imaging studies it was found that serotonin especially in the prefrontal area of the cortex contributes to the clinical symptoms of $\mathrm{ADHD}^{(6,32)}$ Prefrontal cortex plays a role in regulating attention, cognitive function, emotional regulation and motivation $(34,35)$ Serotonin plays an important role in the development of the nervous system in early child development and has a different role with serotonin in adulthood Serotonin affects the symptoms of hyperactivity and impulsivity but has no effect on ${ }^{(34,35)}$. The statistical analysis of serotonin revealed a significant differences between ADHD and non-ADHD subjects. These new findings may provide input for alternative pharmacotherapy management other than methylphenidate because not all parents agree with the administration of these drugs that have side effects on decreased appetite and inhibit the growth of the child.

\section{Conclusion}

Serotonin level in ADHD children was significantly higher than in non-ADHD children.

Ethical Clearance: Taken from Health Research Ethics Committee Faculty of Medicine Airlangga University No. 212/EC/KEPK/FKUA/2018

\section{Source of Funding: Self}

\section{Conflict of Interest: Nil}

\section{References}

1. Shin D, Ph D, Kim E, Oh K, Ph D. The Relationship between Hair Zinc and Lead Levels and Clinical Features of Attention-Deficit Hyperactivity Disorder. 2014;25(1):28-36.

2. Shimabukuro S, Daley D, Thompson M, LaverBradbury C, Nakanishi E, Tripp G. Supporting Japanese Mothers of Children with ADHD: Cultural Adaptation of the New Forest Parent Training Programme. Jpn Psychol Res. 2017;59(1):35-48.

3. Scott S. Parenting programmes for attachment and conduct problems. Psychiatry. 2008;7(9):367-70.

4. Derakhshanpoor F, Khaki S, Vakili A, Shahini N. Study of the Status of Mental Health in 
Mothers with Parenting Style in the Children with Attention Deficit and Hyperactivity Disorder (ADHD). Eur Psychiatry [Internet]. Elsevier Ltd; 28AD;30, Supple(0):578. Available from: http://www.sciencedirect.com/science/article/pii/ S0924933815304594

5. Theule J, Wiener J, Tannock R, Jenkins JM. Parenting Stress in Families of Children With ADHD: A Meta-Analysis. J Emot Behav Disord. 2013;21(1):3-17.

6. Paule MG, Rowland AS, Ferguson SA, Chelonis JJ, Tannock R, Swanson JM, et al. Attention deficit/hyperactivity disorder: Characteristics, interventions and models. Neurotoxicol Teratol. 2000;22(5):631-51.

7. Nixon RDV. Treatment of behavior problems in preschoolers. Clin Psychol Rev. 2002;22(4):52546.

8. Frei H, von Ammon K, Thurneysen A. Treatment of hyperactive children: Increased efficiency through modifications of homeopathic diagnostic procedure. Homeopathy. 2006;95(3):163-70.

9. Biederman J. Attention deficit hyperactivity disorder (ADHD). Ann Clin Psychiatry. 1991;3(1):9.

10. de Graaf R, Kessler RC, Fayyad J, ten Have M, Alonso J, Angermeyer M, et al. The prevalence and effects of adult attention-deficit/hyperactivity disorder (ADHD) on the performance of workers: results from the WHO World Mental Health Survey Initiative. Occup Environ Med [Internet]. 2008;65(12):835-42. Available from: http://oem. bmj.com/cgi/doi/10.1136/oem.2007.038448

11. Chronis AM, Chacko A, Fabiano GA, Wymbs BT, Pelham, Jr. WE. Enhancements to the behavioral parenting training paradigm for families of children with ADHD: Review and future directions. Clin Child Fam Psychol Rev [Internet]. 2004;7(1):127. Available from: http://link.springer.com/ article/10.1023/B:CCFP.0000020190.60808.a4

12. Motlagh MG, Katsovich L, Thompson N, Lin H, Kim YS, Scahill L, et al. Severe psychosocial stress and heavy cigarette smoking during pregnancy: An examination of the pre- and perinatal risk factors associated with ADHD and Tourette syndrome. Eur Child Adolesc Psychiatry. 2010;19(10):755-64.

13. Visser SN, Bitsko RH, Danielson ML, Ghandour RM, Blumberg SJ, Schieve LA, et al. Treatment of attention deficit/hyperactivity disorder among children with special health care needs. J Pediatr [Internet]. Elsevier Inc; 2015;166(6):1423-30. e2. Available from: http://dx.doi.org/10.1016/j. jpeds.2015.02.018

14. Chronis AM, Jones HA, Raggi VL. Evidencebased psychosocial treatments for children and adolescents with attention-deficit/hyperactivity disorder. Clin Psychol Rev. 2006;26(4):486-502.

15. Kleinman RE, Brown RT, Cutter GR, Dupaul GJ, Clydesdale FM. A research model for investigating the effects of artificial food colorings on children with ADHD. Pediatrics. 2011;127(6):e1575-84.

16. Trent $\mathrm{S}$, Davies $\mathrm{W}$. The influence of sexlinked genetic mechanisms on attention and impulsivity. Biol Psychol [Internet]. Elsevier B.V.; 2012;89(1):1-13. Available from: http://dx.doi. org/10.1016/j.biopsycho.2011.09.011

17. Spencer TJ, Biederman J, Mick E. AttentionDeficit/Hyperactivity Disorder: Diagnosis, Lifespan, Comorbidities, and Neurobiology. 2007;32(6):631-42.

18. Oades RD. The Role of Serotonin in AttentionDeficit Hyperactivity Disorder (ADHD). In: Muller C, Jacobs B, editors. Handbook of Behavioral Neurobiology of Serotonin [Internet]. 1st ed. London: Elsevier B.V.; 2010. p. 565-84. Available from: http://linkinghub.elsevier.com/retrieve/pii/ S1569733910701016

19. Oades RD. Role of the serotonin system in ADHD : treatment implications. 2007;1357-74.

20. Marshall R, Neill P, Theodosiou L. Prevalence of attention deficit hyperactivity symptoms in parents of children diagnosed with the condition. Procedia - Soc Behav Sci [Internet]. Elsevier B.V.; 2011;15:3056-8. Available from: http://dx.doi. org/10.1016/j.sbspro.2011.04.244

21. T.D. B, F. M. Environmental risk factors for attention-deficit hyperactivity disorder. Acta Paediatr Int J Paediatr [Internet]. 2007;96(9):126974. Available from: http://ovidsp.ovid.com/ ovidweb.cgi? $\mathrm{T}=\mathrm{JS} \quad \& \quad \mathrm{PAGE}=$ reference $\quad \&$ $\mathrm{D}=\mathrm{emed} 8$ \& NEWS $=\mathrm{N}$ \& $\mathrm{AN}=2007414048$

22. Bolfer C, Pacheco SP, Tsunemi MH, Carreira WS, Casella BB, Casella EB. Attentiondeficit/hyperactivity disorder: The impact of methylphenidate on working memory, inhibition capacity and mental flexibility. Arq Neuropsiquiatr [Internet]. 2017;75(4):204-8. Available from: 
http://www.scielo.br/pdf/anp/v75n4/0004-282Xanp-75-04-0204.pdfinhttp://ovidsp.ovid.com/ ovidweb.cgi? $=$ JS \& $\mathrm{PAGE}=$ reference $\& \mathrm{D}=\mathrm{emex}$ $\&$ NEWS $=\mathrm{N}$ \& $\mathrm{AN}=615927137$

23. Graham J, Seth S, Coghill D. Adhd. Medicine (Baltimore). 2007;35(3):181-5.

24. Karabekiroglu K, Yazgan YM, Dedeoglu C. Can we predict short-term side effects of methylphenidate immediate-release? Int J Psychiatry Clin Pract. 2008;12(1):48-54.

25. Wigal SB, Gupta S, Greenhill L, Posner K, Lerner M, Steinhoff K, et al. Pharmacokinetics of Methylphenidate in Preschoolers with AttentionDeficit/Hyperactivity Disorder. J Child Adolesc Psychopharmacol [Internet]. 2007;17(2):153-64. Available from: http://www.liebertonline.com/doi/ abs/10.1089/cap.2007.0043

26. Southammakosane C, Schmitz K. Pediatric Psychopharmacology for Treatment of ADHD, Depression, and Anxiety. Pediatrics [Internet]. 2015;136(2):351-9. Available from: http:// pediatrics.aappublications.org/cgi/doi/10.1542/ peds.2014-1581

27. Kollins SH. ADHD, substance use disorders, and psychostimulant treatment: Current literature and treatment guidelines. $\mathrm{J}$ Atten Disord. 2008;12(2):115-25.

28. Iris RFÆ, Sam MÆ. ADHD, Temperament, and Parental Style as Predictors of the Child' $s$ Attachment Patterns. 2006;103-14.

29. Biederman J, Spencer T, Wilens T. S P E C IA L Evidence-based pharmacotherapy for attentiondeficit hyperactivity disorder. 2018;(July):77-97.

30. Li JJ, Lee SS. Negative emotionality mediates the association of 5-HTTLPR genotype and depression in children with and without ADHD. Psychiatry Res [Internet]. Elsevier; 2014;215(1):163-9. Available from: http://dx.doi.org/10.1016/j. psychres.2013.10.026

31. Cadoret RJ, Langbehn D, Caspers K, Troughton EP, Yucuis R, Sandhu HK, et al. Associations of the Serotonin Transporter Promoter Polymorphism With Aggressivity, Attention Deficit, and Conduct Disorder in an Adoptee Population. 2003;44(2):88101.

32. Dalley JW, Roiser JP. Dopamine, serotonin and impulsivity. Neuroscience [Internet]. IBRO; 2012;215:42-58. Available from: http://dx.doi. org/10.1016/j.neuroscience.2012.03.065

33. Aktepe E, Ozkorumak E, Tanriover-Kandil S. Pregnancy and delivery complications and treatment approach in attention deficit hyperactivity disorder. Turk J Pediatr [Internet]. 2009;51(5):478-84. Available from: http://www. turkishjournalpediatrics.org/pediatrics/pdf/pdf TJP_693.pdf \nhttp://ovidsp.ovid.com/ovidweb. cgi? $=\mathrm{JS} \&$ PAGE $=$ reference \& $\mathrm{D}=$ emed9 \& NEWS $=\mathrm{N} \& \mathrm{AN}=2010096213$

34. Richardson JR, Taylor MM, Shalat SL, Guillot TS, Caudle WM, Hossain MM, et al. Developmental pesticide exposure reproduces features of attention deficit hyperactivity disorder. FASEB J. 2015;29(5):1960-72.

35. Villagomez A, Ramtekkar U. Iron, Magnesium, Vitamin D, and Zinc Deficiencies in Children Presenting with Symptoms of Attention-Deficit/ Hyperactivity Disorder. Children [Internet]. 2014;1(3):261-79. Available from: http://www. mdpi.com/2227-9067/1/3/261/ 